\title{
Potential of three microbial bio-effectors to promote maize growth and nutrient acquisition from alternative phosphorous fertilizers in contrasting soils
}

\author{
Cécile Thonar ${ }^{1 *}\left(\mathbb{D}\right.$, Jonas Duus Stevens Lekfeldt ${ }^{2}$, Vincenza Cozzolino ${ }^{3}$, Dominika Kundel ${ }^{1}$, Martin Kulhánek ${ }^{4}$, \\ Carla Mosimann ${ }^{1,5}$, Günter Neumann ${ }^{6}$, Alessandro Piccolo ${ }^{3}$, Martin Rex ${ }^{7}$, Sarah Symanczik , Florian Walder ${ }^{1,8}$, \\ Markus Weinmann ${ }^{6}$, Andreas de Neergaard ${ }^{2}$ and Paul Mäder ${ }^{1}$
}

\begin{abstract}
Background: Agricultural production is challenged by the limitation of non-renewable resources. Alternative fertilizers are promoted but they often have a lower availability of key macronutrients, especially phosphorus (P). Biological inoculants, the so-called bio-effectors (BEs), may be combined with these fertilizers to improve the nutrient use efficiency.

Methods: The goal of this study was to assess the potential of three BEs in combination with alternative fertilizers (e.g., composted manure, biogas digestate, green compost) to promote plant growth and nutrient uptake in soils typical for various European regions. Pot experiments were conducted in Czech Republic, Denmark, Germany, Italy, and Switzerland where the same variety of maize was grown in local soils deficient in $\mathrm{P}$ in combination with alternative fertilizers and the same set of BEs (Trichoderma, Pseudomonas, and Bacillus strains). Common guidelines for pot experiment implementation and performance were developed to allow data comparison, and soils were analyzed by the same laboratory.

Results: Efficiency of BEs to improve maize growth and nutrient uptake differed strongly according to soil properties and fertilizer combined. Promising results were mostly obtained with BEs in combination with organic fertilizers such as composted animal manures, fresh digestate of organic wastes, and sewage sludge. In only one experiment, the nutrient use efficiency of mineral recycling fertilizers was improved by BE inoculation.
\end{abstract}

Conclusions: These BE effects are to a large extent due to improved root growth and P mobilization via accelerated mineralization.

Keywords: Biofector, Bio-effector, Bio-inoculants, Bacillus, Pseudomonas, Trichoderma, Maize, Organic fertilizer, PGPR, Phosphorus, Recycling fertilizer

\section{Background}

To meet global demands for agricultural crops, farming systems in industrialized countries have undergone profound transformations. On the one hand, high application

\footnotetext{
*Correspondence: cecile.thonar@fibl.org; cecile.thonar@gmail.com 1 Soil Sciences Department, Research Institute of Organic Agriculture FiBL, Ackerstrasse 113, 5070 Frick, Switzerland
}

Full list of author information is available at the end of the article rates of synthetic fertilizers and manure together with the use of pesticides, irrigation, and short crop rotations have increased yields and have helped to reduce hunger in these countries [1]. On the other hand, modern high-input agriculture has created a multitude of environmental problems. In this context, groundwater pollution and the eutrophication of aquatic systems due to soil erosion and nutrient leaching and run-off from agricultural fields are of great concern $[1,2]$. Additionally, the extensive use of synthetic 
fertilizers is contributing to climate change as fertilizer production and use cause significant greenhouse gas emissions [3]. Moreover, for some plant nutrients such as phosphorous $(\mathrm{P})$, natural fixation processes in soil leads to a decrease in the efficiency of the fertilizers as only a fraction of the applied P fertilizer is taken up by plants. Depending on the soil $\mathrm{pH}$ and mineralogy, a considerable amount of $P$ fertilizers gets either adsorbed to iron, aluminum oxides, or calcium and is no longer directly available to the plant [4]. Consequently, surplus fertilizer inputs are often maintained to meet the crop's demands. Finally, commonly used $P$ fertilizers in modern agriculture are regarded as nonrenewable resources with a limited supply, and the reserves are concentrated in a few countries around the globe $[4,5]$. Hence, judicious use of the resource by effective recycling is required for long-term sustainability.

Today, increasing attention is being paid to the downside of high-input agricultural systems and much research is aimed at developing alternative ways to produce sufficient food in a sustainable and environmentally sound way. A number of different approaches have been investigated with the intention to reduce fertilizer inputs into agroecosystems, including breeding plant varieties with better P acquisition efficiency [6], fertilizer placement strategies [7], or application of soil organisms and natural extracts with plant growth-promoting potential [8-10]. These so-called bio-effectors (BEs) include plant growth-promoting rhizobacteria (PGPR) for instance Pseudomonas and Bacillus spp., as well plant-associated fungi, such as arbuscular mycorrhizal fungi (AMF) or Trichoderma spp. [11]. Moreover, BEs comprise nonliving agricultural bio-stimulants (ABs) such as extraction products from macroalgae, compost, and plants [12]. The plant growth-promoting effect of BEs is based on different mechanisms, for example, the control of plant pathogens either by stimulation of the plant's defense mechanisms or by microbial antagonism [11, 13]. Some BEs induce plant growth by stimulating the plant's own hormone production such as auxins or cytokinins [13, $14]$, or by producing directly hormone-like compounds [15]. Regarding P acquisition, some BEs are associated with increased phosphatase activities in the soil [16-18] and have also shown the ability to liberate $\mathrm{P}$ from soil particles $[9,16,19,20]$ and from P-recycling fertilizers $[21,22]$. Another important mechanism is based on the so-called "mycorrhiza helper" effect [23] which has been observed for many bacterial BEs [24]. This term refers to a stimulation of AMF which fulfill important functions regarding $P$ uptake by plants.

Although BEs have shown the potential to promote plant growth, their effectiveness is influenced by numerous biotic and abiotic factors. Consequently, depending on the properties of the soil and the structure of the naturally occurring rhizosphere community, their plant growth-promoting effect has often shown limited reproducibility. As reported in Mosimann [25], soil properties such as $\mathrm{pH}$ can have impacts on the BEs' ability to exert plant growth-promoting effects. Moreover, the amount of total and plant available $\mathrm{P}$ seems to be a decisive factor for the performance of bacterial BEs [26, 27]. Also, competition with naturally occurring rhizosphere microorganisms can limit the survival of introduced BEs [28]. This indicates that more work is needed to unravel the conditions under which BEs can exert plant growth-promoting effects, in order to achieve more homogenous and predictable effects. With this new knowledge, specifically adapted BEs could be developed which might improve fertilizer use efficiency and decrease the dependence of agriculture on large external inputs of synthetic fertilizers.

Maize (Zea mays), a major crop globally, is particularly sensitive to low phosphorus availability [29] and has shown responsiveness to $\mathrm{BE}$ applications [30-32]. For this reason, maize was selected as the study crop to evaluate the potential of three BEs: the bacterial BEs Pseudomonas sp. DSMZ 13134 and Bacillus amyloliquefaciens FZB42 and the fungal BE Trichoderma harzianum T-22. We applied all BEs individually in combination with different organic and inorganic P fertilizers in order to study the impact of the different $\mathrm{P}$ sources on the BEs' ability to promote $\mathrm{P}$ acquisition and growth of maize. In order to shed more light on the impact of soil properties on the effectiveness of the applied BEs, we used six soils originating from different sites in Europe. We hypothesized that $\mathrm{BE}$ application improves plant $\mathrm{P}$ acquisition from soil and from recycling fertilizers, and that soil properties, e.g., $\mathrm{pH}$ and $\mathrm{P}$ levels (total $\mathrm{P}$ and plant available $\mathrm{P}$ ), influence the effectiveness of the three BEs.

\section{Methods}

\section{Overall experimental design}

Maize growth (variety Colisée, KWS Saat, Germany) was investigated in pots using soils collected from six different sites (Table 1) and by applying a factorial design including the two following factors: $\mathrm{P}$ fertilizer (minimum 3 levels) and microbial BE application (2-4 levels). Table 2 gives an overview of the treatments applied to each soil.

\section{Collection of soils and soil characterization}

Topsoil was collected from the six different locations. The soils were characterized by one analytical lab (LA Chemie, University of Hohenheim, Germany) for $\mathrm{pH}$ $\left(0.01 \% \mathrm{CaCl}_{2}\right)$, texture, organic carbon content [33], and plant available soil P (CAL method for neutral and alkaline soils [33] and DL method for acidic soils [33]). Additional information regarding geographic origin of the 
Table 1 Soil characteristics

\begin{tabular}{|c|c|c|c|c|c|c|c|c|c|}
\hline \multirow[t]{3}{*}{ Soil-ID } & \multirow[t]{3}{*}{ Geographic origin } & \multirow[t]{3}{*}{ Management } & \multirow[t]{3}{*}{ Soil type } & \multicolumn{3}{|c|}{ Texture } & \multirow{3}{*}{$\begin{array}{l}\text { Soil } \\
\text { pH } \\
\left(\mathrm{CaCl}_{2}\right)\end{array}$} & \multirow{3}{*}{$\begin{array}{l}\text { Corg } \\
\text { (\%) }\end{array}$} & \multirow{3}{*}{$\begin{array}{l}\text { Phosphorus } \\
\text { CAL/DL } \\
\left(\mathrm{mg} \mathrm{P} \mathrm{kg}^{-1}\right)\end{array}$} \\
\hline & & & & Clay & Sand & Silt & & & \\
\hline & & & & (\%) & $(\%)$ & (\%) & & & \\
\hline 1-Buus ${ }^{\mathrm{a}}$ & $\begin{array}{l}\text { Buus } \\
\text { (Switzerland) }\end{array}$ & $\begin{array}{l}\text { Rotation: Lay rotation } \\
\text { Fertilization: organic, low input } \\
\text { Site type: farmer field site }\end{array}$ & Loamy soil & 29.9 & 3.90 & 66.2 & 6.6 & 2.64 & 6.5 \\
\hline 2-Castel ${ }^{a}$ & $\begin{array}{l}\text { Castel Volturno } \\
\text { (Italy) }\end{array}$ & $\begin{array}{l}\text { Rotation: Maize-clover } \\
\text { Fertilization: mineral, low input } \\
\text { Site type: farmer field site }\end{array}$ & Vertic Xerofluvent & 36.5 & 19.0 & 44.5 & 7.3 & 1.34 & 19.2 \\
\hline 3-Humpolec ${ }^{a}$ & $\begin{array}{l}\text { Humpolec } \\
\text { (Czech Republic) }\end{array}$ & $\begin{array}{l}\text { Rotation: P-WW-SBC } \\
\text { Fertilization: mineral, low input } \\
\text { Site type: experimental station }\end{array}$ & $\begin{array}{l}\text { Cambisol } \\
\text { Loamy sand }\end{array}$ & 15.9 & 52.9 & 31.2 & 5.2 & 1.63 & $45.0 / 59.8$ \\
\hline 4-Lukavec ${ }^{a}$ & $\begin{array}{l}\text { Lukavec } \\
\text { (Czech Republic) }\end{array}$ & $\begin{array}{l}\text { Rotation: long-term protection area } \\
\text { around field experiment } \\
\text { Fertilization: none } \\
\text { Site type: experimental station }\end{array}$ & $\begin{array}{l}\text { Cambisol } \\
\text { Loamy sand }\end{array}$ & 14.0 & 56.0 & 30.0 & 5.4 & 1.5 & $48.0 / 49.8$ \\
\hline 5-Vörden ${ }^{b}$ & $\begin{array}{l}\text { Vörden } \\
\text { (Germany) }\end{array}$ & $\begin{array}{l}\text { Rotation: before } 2009 \text { grazing area } \\
\text { for wildlife - since } 2009 \text { field forage } \\
\text { cultivation } \\
\text { Fertilization: low input (organic and } \\
\text { mineral) } \\
\text { Site type: farmer field site }\end{array}$ & Cambisol & 12.0 & 41.1 & 46.9 & 5.0 & 0.72 & $11.4 / 9.4$ \\
\hline 6-Taastrup ${ }^{a}$ & $\begin{array}{l}\text { Taastrup } \\
\text { (Denmark) }\end{array}$ & $\begin{array}{l}\text { Rotation: Barley-barley } \\
\text { Fertilization: no P fertilizer since } 1964 \\
\text { Site type: long-term field trial }\end{array}$ & Sandy loam & 13.4 & 55.4 & 31.2 & 5.8 & 1.09 & $15.3 / 17.9$ \\
\hline
\end{tabular}

soils, management of the sites, and soil type is given in Table 1. Most soils had low to very low levels of available $\mathrm{P}$, which makes them ideal for testing the efficiency of BEs in improving $\mathrm{P}$ availability and/or P uptake of added fertilizers by maize. The $\mathrm{pH}$ was ranging from slightly acidic to medium alkaline.

\section{BE treatments}

The three BE strains tested (Table 3) were formulated within three commercial products, namely TrianumP (Koppert, The Netherlands) containing Trichoderma harzianum strain T-22 (BE1), Proradix WP (Sourcon Padena, Germany) containing Pseudomonas sp. strain DSMZ 13134 (BE2), and Rhizo Vital 42 fl. (Abitep, Germany) containing Bacillus amyloliquefaciens strain FZB42 (BE3). The choice of these three BEs is based on their published ability to act as potential bio-stimulants and biofertilizers. The strain Trichoderma harzianum Rifai 1295-22 (T22) has demonstrated abilities to increase the solubilization of sparingly soluble calcium phosphates [34] and to promote plant growth in various plant species [35, 36] including maize [37]. The strain Pseudomonas DSMZ 13134 is an efficient root colonizer
[38] and has been shown to solubilize inorganic phosphate under in vitro conditions [39]. Moreover, it has recently shown the potential to improve plant growth and phosphorus acquisition when inoculated to maize $[10,25]$. The gram-positive strain Bacillus amyloliquefaciens FZB42 is mainly studied for its biocontrol potential but other studies also indicate its ability to act as a biofertilizer $[40,41]$. The Trichoderma strain was inoculated at a concentration of $2.5 \times 10^{4}$ spores per $g$ of substrate and the two bacterial strains at a concentration of $2 \times 10^{6} \mathrm{cfu}$ per $g$ of substrate. A non-inoculated control (BE0) was included for every soil and in combination with every $\mathrm{P}$ treatment. The exact amount of inoculated cells or spores in the different products was checked in preliminary work where inoculation suspensions were plated on specific media and counted afterward. This has led to a standardized inoculation protocol that was later applied for all pot experiments.

\section{P fertilization treatments}

The three common $\mathrm{P}$ treatments were negative control without the addition of $\mathrm{P}$ fertilizer (P0), Triple Super Phosphate (TSP), and Rock Phosphate (RP). In most 
Table 2 Overview of the experimental design and setup at the different locations (1: Switzerland, 2: Italy, 3 and 4: Czech Republic, 5: Germany, 6: Denmark)

\begin{tabular}{|c|c|c|c|c|c|c|}
\hline & 1-Buus & 2-Castel & 3-Humpolec & 4-Lukavec & 5-Vörden & 6-Taastrup \\
\hline \multicolumn{7}{|l|}{ Factors tested (experimental design) } \\
\hline \multicolumn{7}{|l|}{ Crop } \\
\hline Maize (variety: Colisée) & $x$ & $x$ & $x$ & $x$ & $x$ & $x$ \\
\hline \multicolumn{7}{|l|}{ Bio-effectors } \\
\hline No bio-effectors (BE0) & $x$ & $x$ & $x$ & $x$ & $x$ & $x$ \\
\hline BE1:Trianum-P & $x$ & $x$ & $x$ & $x$ & & \\
\hline BE2: Proradix & $x$ & $x$ & $x$ & $x$ & $x$ & $x$ \\
\hline BE3: Rhizovital & $x$ & $x$ & $x$ & $x$ & $x$ & \\
\hline \multicolumn{7}{|l|}{ Fertilizers } \\
\hline No P fertilizer (P0) & $x$ & $x$ & $x$ & $x$ & $x$ & $x$ \\
\hline Triple Super phosphate & $x$ & $x$ & $x$ & $x$ & $x$ & \\
\hline Rock phosphate & $x$ & $x$ & $x$ & $x$ & $x$ & \\
\hline Local sewage sludge ashes & & & & & $x$ & $x$ \\
\hline P-enriched BOF slag & & & & & $x$ & \\
\hline Fresh Digestate & $x$ & & & & & \\
\hline Local composts & $x$ & & & & $x$ & \\
\hline Composted cattle manure & & $x$ & & & & \\
\hline Composted horse manure & & $x$ & & & & \\
\hline Local sewage sludges & & & & & $x$ & $x$ \\
\hline \multicolumn{7}{|l|}{ Experimental setup } \\
\hline Amount of substrate per pot (kg-DW equivalent) & 2.5 & 2.5 & 5 & 5 & 5 & 2.5 \\
\hline Number of plants per pot at harvest & 1 & 1 & 3 & 3 & 1 & 1 \\
\hline Growth period (weeks) & 8 & 8 & 15 & 15 & 8 & 6.5 \\
\hline Number of replicates & 5 & 5 & 5 & 5 & 4 & 3 \\
\hline Soil to sand ratio & $2: 1$ & $2: 1$ & $2: 1$ & $2: 1$ & $2: 1$ & $1: 1$ \\
\hline Growing facilities ${ }^{a}$ & GC & GC & $\mathrm{GH}$ & $\mathrm{GH}$ & $\mathrm{GH}$ & $\mathrm{GH}$ \\
\hline
\end{tabular}

a GC means growth chamber and GH greenhouse

Table 3 Bio-effector strains applied

\begin{tabular}{|c|c|c|c|c|c|c|}
\hline Product & Producer & Abbr. & Species & Type of organism & Formulation & $\begin{array}{l}\text { Application rate } \\
\text { (cfu g } \text { g }^{-1} \text { soil) }\end{array}$ \\
\hline Control & n.a. & BEO & n.a. & n.a. & n.a. & n.a. \\
\hline Trianum-P & $\begin{array}{l}\text { Koppert, } \\
\text { The Netherlands }\end{array}$ & BE1 & $\begin{array}{l}\text { Trichoderma harzianum, } \\
\text { strain T-22 }\end{array}$ & Fungus & Powder & $2.5 \times 10^{4}$ \\
\hline Proradix WP & Sourcon Padena, Germany & BE2 & Pseudomonas sp. strain DSMZ 13134 & Bacteria & Powder & $2 \times 10^{6}$ \\
\hline Rhizovital $42 \mathrm{fl}$. & ABiTEP, Germany & BE3 & $\begin{array}{l}\text { Bacillus amyloliquefaciens, } \\
\text { strain FZB42 }\end{array}$ & Bacteria & Liquid & $2 \times 10^{6}$ \\
\hline
\end{tabular}

n.a. means not applicable

cases, a number of additional P treatments (Table 4) were investigated and consisted of organic fertilizers and/or recycled inorganic fertilizers. These fertilizers were locally available and previously studied for their properties by the individual groups. As a result, some soils were tested with organic fertilizers and others only with recycled inorganic fertilizers (in addition to TSP and RP). Except for the P0 treatment, all pots received $\mathrm{P}$ at a dose of $50 \mathrm{mg} \mathrm{P}$ per $\mathrm{kg}$ of dry substrate. The TSP $(20 \% \mathrm{P})$ was provided by Landor in Switzerland and RP (12\% P) by Herbert Molitor in Germany. The additional $P$ treatments consisted of recycled inorganic fertilizers (sewage sludge ashes and P-enriched BOF (basic oxygen furnace) slags [42]) and organic fertilizers (fresh biogas digestate, mature compost from green 
Table 4 Main characteristics of the fertilizers used

\begin{tabular}{|c|c|c|c|c|c|c|c|}
\hline Fertilizers & Abbr. & Inorg/org & $\begin{array}{l}\text { Dry matter } \\
\text { content (\%) }\end{array}$ & $\begin{array}{l}\text { Total } \mathrm{P} \\
\left(\mathrm{mg} \mathrm{P} \mathrm{g}^{-1}\right)\end{array}$ & $\begin{array}{l}\text { Water extractable } \mathrm{P} \\
\left(\mathrm{mg} \mathrm{P} \mathrm{g}^{-1}\right)\end{array}$ & $\begin{array}{l}\text { Total N } \\
\left(\mathrm{mg} \mathrm{N} \mathrm{g}^{-1}\right)\end{array}$ & $\begin{array}{l}\text { Ammonium } \\
\left(\mathrm{NH}_{4}^{+}-\mathrm{N}\right) \\
\left(\mathrm{mg} \mathrm{N} \mathrm{g}^{-1}\right)\end{array}$ \\
\hline Triple super phosphate & TSP & Inorg & 100 & 201.0 & 201.0 & 0 & 0 \\
\hline Rock phosphate & $\mathrm{RP}$ & Inorg & 100 & 115.4 & 0.22 & 0 & 0 \\
\hline Sewage sludge ashes (Germany) & SSA-DE & Inorg & 100 & 103.5 & 0.79 & n.d. & n.d. \\
\hline Sewage sludge ashes (Denmark) & SSA-DK & Inorg & 100 & 89 & n.d. & n.d. & n.d. \\
\hline P-enriched BOF slag (Germany) & LSD/SSA & Inorg & 100 & 18.0 & 0.0 & n.d. & n.d. \\
\hline Fresh digestate (Switzerland) & FrDi & Org & 48.0 & 4.36 & 0.130 & 14.6 & 0.61 \\
\hline Compost (Switzerland) & Comp-CH & Org & 59.6 & 2.45 & 0.043 & 10.4 & 0.24 \\
\hline Compost (Germany) & Comp-DE & Org & 57.2 & 1.42 & 0.67 & n.d. & n.d. \\
\hline Composted cattle manure (Italy) & C-MComp & Org & 60.0 & 7.75 & n.d. & 22.7 & n.d. \\
\hline Composted horse manure (Italy) & H-MComp & Org & 67.0 & 10.0 & n.d. & 14.2 & n.d. \\
\hline Sewage sludge (Germany) & SS-DE & Org & 99 & 38.1 & 0.52 & n.d. & n.d. \\
\hline Sewage sludge (Denmark) & SS-DK & Org & 23.0 & 30.4 & 1.5 & n.d. & n.d. \\
\hline
\end{tabular}

n.d. means not determined

wastes, composted cow and horse manures, and sewage sludge). They were characterized by the local laboratories (Table 4) for their dry matter content, total P content, water extractable $\mathrm{P}$, total potassium $(\mathrm{K})$ and $\mathrm{N}$ content, and their ammonium $\mathrm{N}$ content.

\section{Pot experiment setup, growing conditions, and harvest}

After sieving, the soil was mixed with quartz sand (0.6$1.2 \mathrm{~mm}$ ) in the ratio $2: 1$ or $1: 1$ (soil dry weight (DW)/ sand DW; W/W). Each pot contained the equivalent of $2.5 \mathrm{~kg}$ or $5 \mathrm{~kg}$ DW of the experimental substrate (Table 2). All pots received $\mathrm{N}$ (100 $\mathrm{mg} \mathrm{N} \mathrm{kg}^{-1}$ substrate) and $\mathrm{K}$ (166 mg K kg ${ }^{-1}$ substrate) in form of calcium nitrate and Kalimagnesia, respectively. Where alternative $\mathrm{P}$ treatments were applied, $\mathrm{N}$ and $\mathrm{K}$ were measured and reduced from the basal dose of $\mathrm{N}$ and $\mathrm{K}$ (except for the German and the Danish trials where the addition of $\mathrm{N}$ and $\mathrm{K}$ was not reduced).

The $\mathrm{N}, \mathrm{K}$, and $\mathrm{P}$ fertilizers were added individually to every pot, and water addition was adjusted to reach $60-70 \%$ of the substrates water holding capacity (WHC). Three seeds were sown per pot, and the BE suspension was added in the seeding hole $(5 \mathrm{ml}$ per seeding hole $=15 \mathrm{ml}$ per pot). BE suspensions were prepared under sterile conditions by diluting the products with $2.5 \mathrm{mM} \mathrm{CaSO}_{4}$. The surface of the pots was then covered by a fine layer of quartz sand to avoid formation of surface crusts after watering.

The pots were transferred to growth chamber or greenhouse (see Table 2) and watered according to plant's need in order to keep the initial WHC (increased to 70-80\% after two weeks). Thinning (including the root systems) was performed one week after sowing, leaving one plant in each pot. During the growth period, plant height was measured every second week and final harvest took place 8 weeks after sowing. Any deviation from this standard protocol (size pot, growing period, number of plant per pot, standard P fertilizers) is described in Table 2. Every treatment was replicated five times (or at minimum three times, see Table 2), and pots were randomly distributed in the growth chambers or greenhouses. The guidelines for establishing the pot experiments were common to all soils, and deviations to experimental setup are due to particular constraints of the different involved groups.

\section{Plant analyses}

At harvest, shoots were collected, dried $\left(65{ }^{\circ} \mathrm{C}\right)$, and stored for further analyses. Root systems were washed from the substrate, and a subsample was kept (only in Swiss and Italian soils) to assess percentage root length colonization (RLC \%) by arbuscular mycorrhizal fungi (AMF) following the protocol of Phillips and Hayman [43] and Brundrett et al. [44]. The remaining root was weighed and dried for total root DW assessment. Dried shoot material was milled for later determination of total $\mathrm{N}$ and $\mathrm{P}$ concentration. Shoot nitrogen concentration was measured using $\mathrm{CHN}$ analyzers, while shoot $\mathrm{P}$ concentration was determined spectrophotometrically or using flow injection analysis (Danish experiment) after acid extraction.

\section{Data analyses and statistics}

Residuals of the data (shoot DW, N and P content in shoot and RLC \%) were tested for normality using the Shapiro-Wilk test. For every soil, a two-way ANOVA was performed to test the significance of each factor 
(P fertilizer and BE strain) and their interaction. Since this interaction was always significant and for the sake of the graphical representation (in Figs. 2, 3, 4, and 5), a one-way ANOVA was performed within each $P$ treatment and for each soil to determine which $\mathrm{BE}$ treatment (BE1, BE2, or BE3) was significantly different from the un-inoculated controls (Tukey's test, $P<0.05)$. Due to differences in growing conditions (Table 2, lower part) leading to substantial differences in the aboveground biomass response among single experiments, we normalized the aboveground biomass, $\mathrm{P}$, and $\mathrm{N}$ content relative to the negative control treatment $(\mathrm{P} 0, \mathrm{BE} 0)$ in the following way (exemplified for biomass):

$$
\text { normalized biomass }_{\text {sample }}=\frac{\text { biomass }_{\text {sample }}}{\overline{\text { biomass }_{\text {control }(P 0, B E 0)}}}
$$

Furthermore, in order to quantify the relative effect of $\mathrm{BE}$ additions across soils and P fertilizer types, absolute values for shoot DW (g plant ${ }^{-1}$ ) were converted to shoot biomass improvement (in \%) for every BE (BE1, BE2, and $\mathrm{BE} 3)$ calculated relative to the BE0 control. For this, we applied the following equation:

improvement\%

$$
=100 \cdot\left(\frac{\text { biomass }_{\text {sample }\left(P_{x}, B E_{y}\right)}-\overline{\operatorname{biomass}_{\text {sample }\left(P_{x}, B E_{0}\right)}}}{\overline{\operatorname{biomass}_{\text {sample }\left(P_{x}, B E_{0}\right)}}}\right)
$$

A value of $0 \%$ means that the shoot biomass of maize inoculated with the BE strain in question did not improve shoot biomass as compared to the un-inoculated control (using the same $\mathrm{P}$ fertilizer), whereas a value below or above $0 \%$ indicates that the specific $\mathrm{BE}$ treatment led to a decrease or an increase in aboveground biomass, respectively. In order to investigate the relative effect of BEs across different experiments, we categorized the added $P$ fertilizers as either organic or inorganic. Data from experiments conducted in the Czech Republic were not considered here as they only included inorganic fertilizers (TSP and RP). For each BE, we performed a separate two-way ANOVA on these data with "soil" and "fertilizer type" and their interaction as factors, in order to analyze if the effect of $\mathrm{BE}$ was dependent on soil and/or fertilizer type (Table 6).

For each fertilizer, the fertilizer efficiency (FE \%) relative to TSP (positive control) was calculated as the mean efficiency measured in $\mathrm{n}$ replicated pots. The efficiency in individual pots was calculated as follows:

$$
F E_{\%}=100 \cdot\left(\frac{\text { biomass }_{\text {sample }}-\overline{\text { biomass }_{\text {control }(P 0, B E 0)}}}{\overline{\text { biomass }_{T S P}}-\overline{\text { biomass }_{\text {control }(P 0, B E 0)}}}\right)
$$

Finally, the P uptake efficiency (PUE \%) from the different fertilizers was calculated as follows:

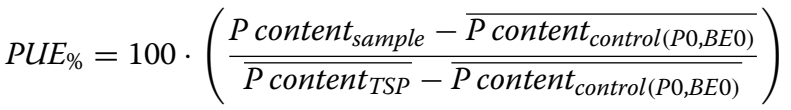

\section{Results}

The aboveground biomass was highly variable across the experiments (Fig. 1). A two-way ANOVA on raw biomass data (Fig. 1) for the negative (P0) and positive controls (TSP) without addition of BE (BE0) yielded highly significant effects of soil $(P<0.001)$ and $P$ fertilizer $(P<0.001)$, as well as a highly significant interaction between the two factors $(P<0.001)$. In five out of six soils, there was a significant positive effect of TSP addition on the aboveground biomass (Fig. 1, Tukey's test, $P<0.05$ ). The Humpolec soil is the only soil not affected by TSP addition with regards to aboveground biomass production.

In absence of $\mathrm{BE}$ inoculation (BE0), plants responded differently to the addition of the various $P$ fertilizers. This was true for normalized biomass (Fig. 2), normalized P content (Fig. 3), and normalized N content (Fig. 4). The most effective fertilizers were the P-enriched BOF slag (Vörden trial) and in general the composted material from green wastes ( $\mathrm{FrDi}$, Comp-CH, Comp-D (see Table 4 for abbr.)) and sewage sludges from Denmark (incinerated or not).

The following combinations of $\mathrm{BE}$ and $\mathrm{P}$ fertilizers resulted in a higher normalized shoot biomass (Fig. 2), when compared to the negative control treatment $(\mathrm{BE} 0)$ receiving the same $\mathrm{P}$ fertilizer (treatments

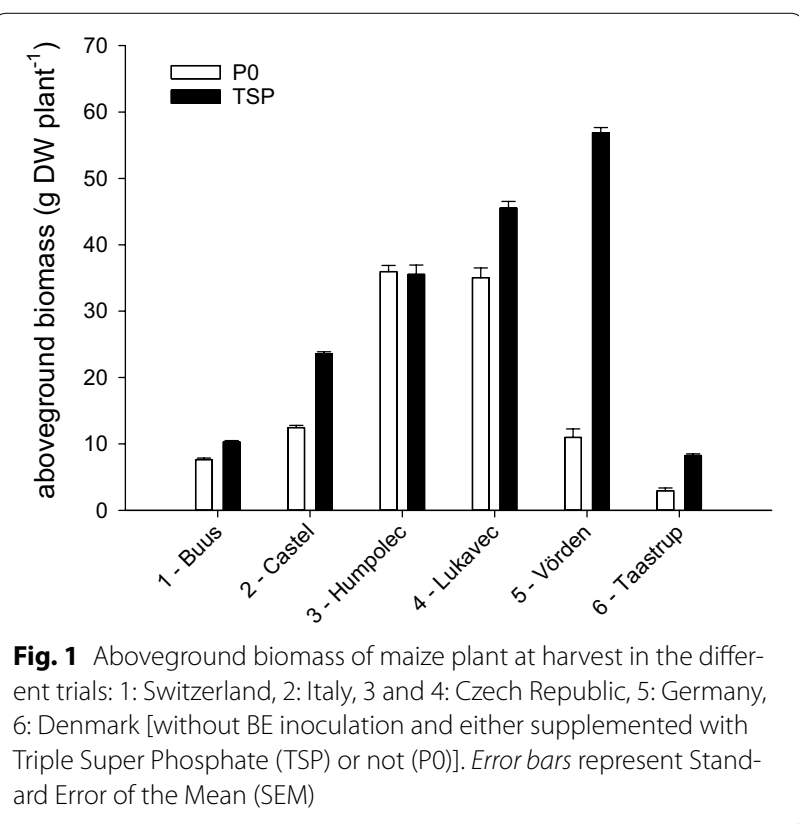



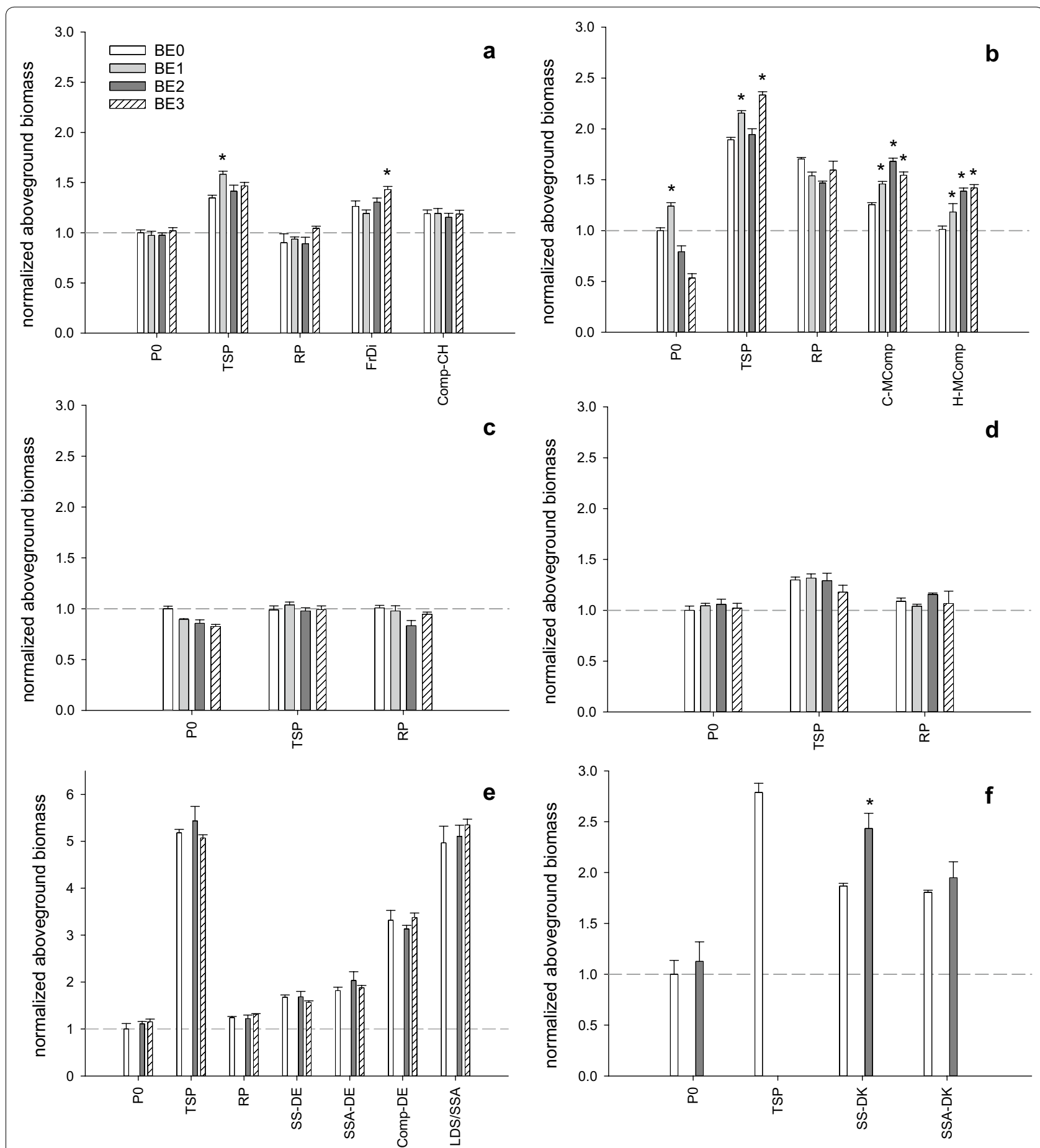

Fig. 2 Normalized aboveground biomass for the different trials: 1-Buus Switzerland (a), 2-Castel Italy (b), 3-Humpolec Czech R. (c), 4-Lukavec Czech R. (d), 5-Vörden Germany (e), 6-Taastrup Denmark (f). Bars represent the mean of five replicates ( $n=4$ for $\mathbf{e}$, and $n=3$ for $\mathbf{f}$ ). Error bars represent SEM. BE treatments (BE1-3) resulting in a significantly higher normalized biomass compared to the BE0 control within each P fertilizer treatment and within each trial are indicated with an asterisk (*Tukey's test with $P<0.05$ ). See Tables 3 and 4 for explanation of BE and $P$ treatment abbreviations

highlighted with an asterisk): BE1 combined with TSP in the Buus (Fig. 2a) and Castel soils (Fig. 2b); BE2 combined with sewage sludge in the Taastrup soil (Fig. 2f);
BE3 combined with fresh digestate and TSP in the Buus (Fig. 2a) and Castel (Fig. 2b) soils, respectively; and all BEs combined with composted animal manures 

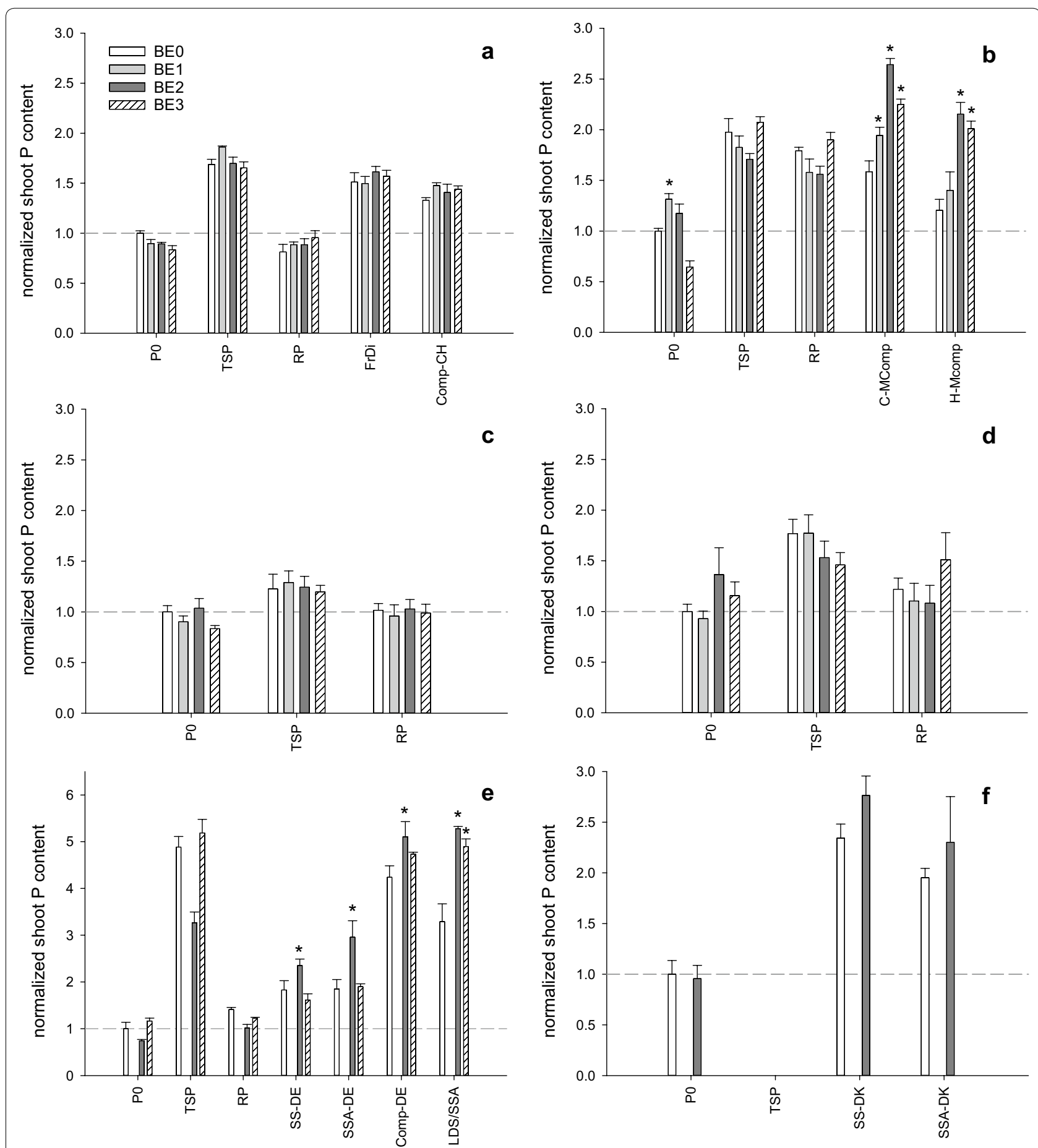

Fig. 3 Normalized aboveground P content for the different trials: 1-Buus Switzerland (a), 2-Castel Italy (b), 3-Humpolec Czech R. (c), 4-Lukavec Czech R. (d), 5-Vörden Germany (e), 6-Taastrup Denmark (f). Bars represent the mean of five replicates ( $n=4$ for $\mathbf{e}$, and $n=3$ for $\mathbf{f}$ ). Error bars represent SEM. BE treatments (BE1-3) resulting in a significantly higher normalized P content compared to the BE0 control within each $P$ fertilizer treatment and within each trial are indicated with an asterisk (*Tukey's test with $P<0.05$ ). See Tables 3 and 4 for explanation of $B E$ and $P$ treatment abbreviations 

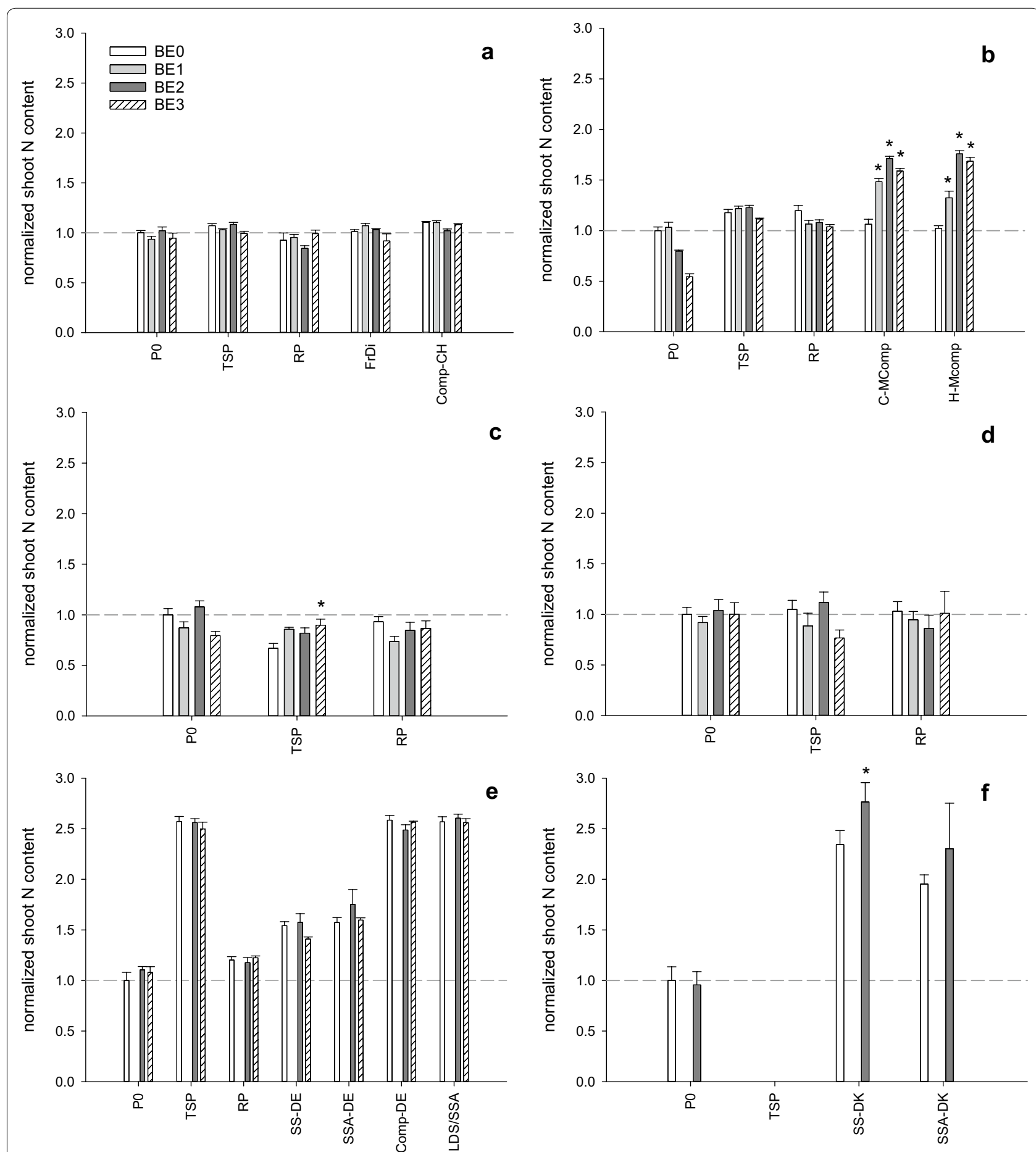

Fig. 4 Normalized aboveground N content for the different trials: 1-Buus Switzerland (a), 2-Castel Italy (b), 3-Humpolec Czech R. (c), 4-Lukavec Czech R. (d), 5-Vörden Germany (e), 6-Taastrup Denmark (f). Bars represent the mean of five replicates ( $n=4$ for $\mathbf{e}$, and $n=3$ for (f). Error bars represent SEM. BE treatments (BE1-3) resulting in a significantly higher normalized N content compared to the BEO control within each P fertilizer treatment and within each trial are indicated with an asterisk (*Tukey's test with $P<0.05$ ). See Tables 3 and 4 for explanation of BE and $P$ treatment abbreviations 
in the Castel soil (Fig. 2b). In the Humpolec, Lukavec, and Vörden soils, BE inoculation did not result in any increased normalized shoot biomass (Fig. $2 \mathrm{c}-\mathrm{e}$ ).

Across the four experiments included in Table 6 (all except the two Czech experiments), BE inoculations induced an increase in shoot DW of 5-7.5\%, as compared to un-inoculated controls (Table 6). For all three tested $\mathrm{BEs}$, soil influenced the BE-derived increase in shoot biomass $(P<0.01)$. When looking across fertilizer types, the largest $\mathrm{BE}$ effects were observed in the Castel soil for BE1 $(+12 \%)$, in the Taastrup soil for BE2 $(+17 \%)$, and in the Buus soil for BE3 (8\%). The factor "fertilizer type" significantly influenced the improvement in biomass when plants were inoculated with BE2 and BE3 (Table 6, $P<0.0001$ ), but no such effect of "fertilizer type" was observed with BE1 (Table $6, P>0.05$ ). Furthermore, there was a significant interaction between "soil" and "fertilizer type" for all BE treatments (Table $6, P<0.0001$ ).

Across all soils, there was a significant positive effect of adding BE2 $(+14 \%)$ and BE3 $(+13 \%)$ when organic fertilizers were applied (Table $6, P<0.05)$. For inorganic fertilizers, there was only a significant effect of BE3 $(+7 \%$, $\mathrm{P}<0.05)$. When no fertilizer was added, none of the three BEs resulted in an improvement of the shoot biomass (Table 6, P > 0.05).

The normalized aboveground $\mathrm{P}$ content was significantly different between $\mathrm{P}$ fertilizers in all experiments (Fig. 3). In the Castel soil, inoculation with BE1 led to a significantly larger P content in the P0 and cow manure compost treatments, while inoculation with BE2 and $\mathrm{BE} 3$ resulted in an increased $\mathrm{P}$ content in both animal manure treatments (Fig. 3b). In the Vörden soil, inoculation with BE2 resulted in an increased $P$ content when combined with any of the recycling fertilizers (Fig. 3e). In the remaining soils (Buus, Humpolec, Lukavec, and Taastrup), BE inoculation did not result in increased aboveground $\mathrm{P}$ contents. In the Castel soil, the higher $\mathrm{P}$ content due to BE2 addition (combined with cow and horse manures) is reflecting the significant increase in $\mathrm{P}$ concentration in the aboveground biomass (Table 7). BE3 increased P concentration only in the P0 treatment, while BE1 did not induce any $\mathrm{P}$ concentration increase. In the Vörden soil, where plants also accumulated more P in the aboveground biomass (Fig. 3e), P concentration was also higher (as compared to the corresponding BEO control), but only when sewage sludge ashes were combined with $\mathrm{BE} 2$ and when P-enriched BOF slags were combined with $\mathrm{BE} 2$ or $\mathrm{BE} 3$.

The normalized aboveground $\mathrm{N}$ content (Fig. 4) showed less difference between $\mathrm{P}$ fertilization treatments than the normalized P content did (Fig. 3). Only in Vörden (Fig. 4e) and Taastrup (Fig. 4f) soils, a clear effect of $\mathrm{P}$ fertilizers on aboveground $\mathrm{N}$ content was observed.
In the Castel soil, the effect of P fertilization depended on $\mathrm{BE}$ addition since we only observed a significantly larger normalized aboveground $\mathrm{N}$ content when pots had been inoculated with BEs 1-3 (Fig. 4b). In the Taastrup soil, a significantly higher aboveground $\mathrm{N}$ content was observed in plants inoculated with BE2 and when sewage sludge was used as fertilizer. In the Humpolec soil, we found a significant increase in aboveground $\mathrm{N}$ content due to inoculation with BE3, when TSP was used as P fertilizer (Fig. 4c). However, the recorded $\mathrm{N}$ content (Fig. 4c) in this treatment (TSP/BE3) was numerically smaller than in the negative control (P0/BE0). In the remaining soils (Buus, Lukavec, and Vörden), BE inoculation did not result in increased aboveground $\mathrm{N}$ contents.

Intensity of RLC \% by AMF was only measured in roots of plants growing in the Buus and Castel soils (Fig. 5). For un-inoculated treatments which were not amended with $\mathrm{P}$ fertilizer (BE0, P0), the two soils induced different

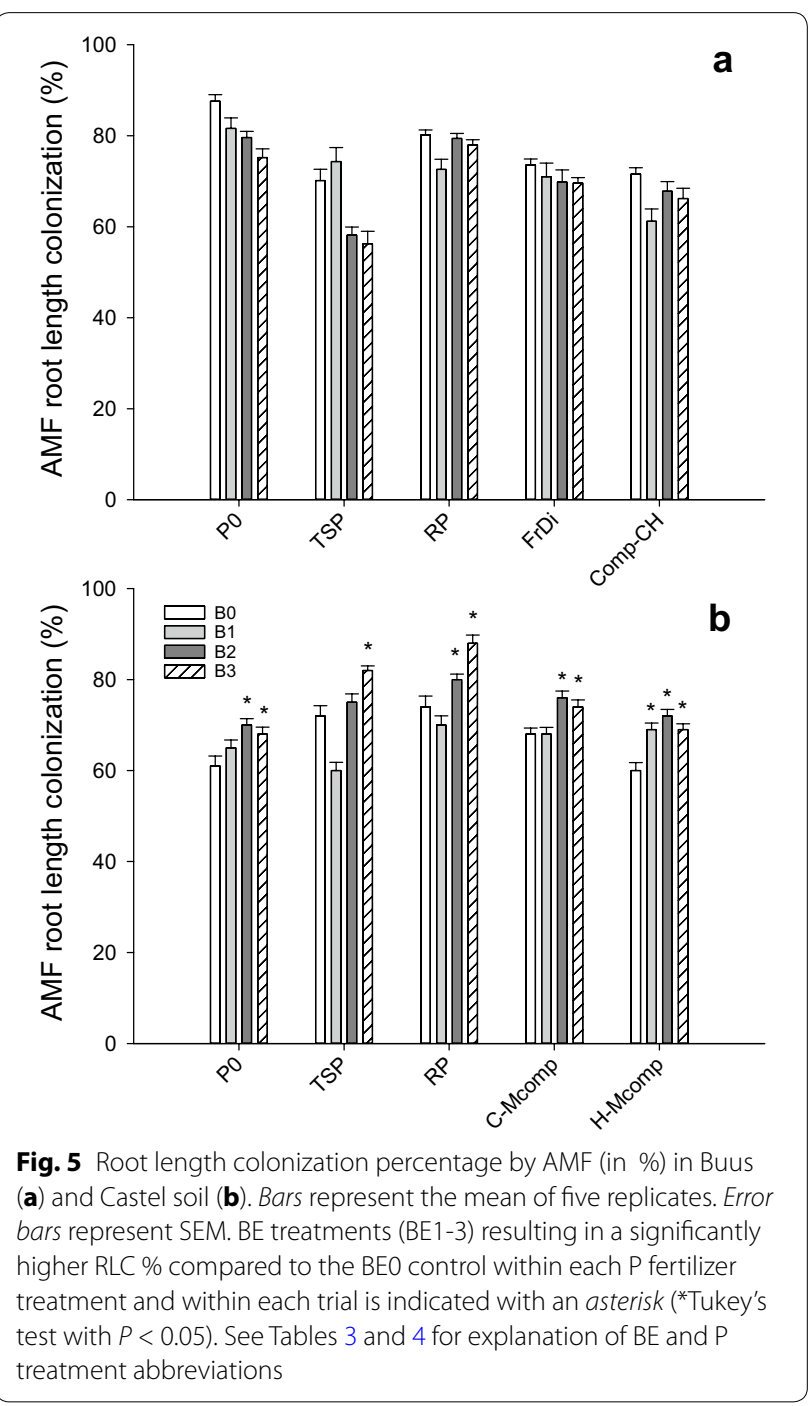


levels of RLC \% (87\% for the Buus soil and $60 \%$ for the Castel soil). In the Buus soil, BE inoculation leads to either no change in RLC \% or a decrease, especially for plants amended with TSP (Fig. 5a). In contrast, the roots from the Castel soil had significantly higher RLC \% in BE-inoculated pots, especially for BE3 (independent of $P$ fertilizer applied) and for the combination of BE2 and animal manures (Fig. 5b).

\section{Discussion}

Variable levels of soil fertility and harvested aboveground biomass (PO, BEO and TSP, BEO)

Due to variation in the experimental setup (e.g., pot size and growth duration), different aboveground biomasses were harvested ranging from 4 to $36 \mathrm{~g}$ per plant in the negative control treatment (P0, BE0). The different increases due to TSP addition (TSP, BE0) indicated that soils had varying initial fertility levels (Figs. 1, 2) with the Czech soils (Humpolec and Lukavec) being the less depleted in P. Plants growing in the Vörden (DE), the Taastrup (DK), and, to a lesser extent, in the Castel (IT) soil, were obviously P limited (increase between 2- to fivefold due to TSP addition), while the plants in the Buus $(\mathrm{CH})$ soil showed a moderate $\mathrm{P}$ increase (1.6-fold). The same response to TSP addition was observed with spring wheat with the Vörden and Taastrup soils [45], where a similar experimental setup was used. The Taastrup soil originates from a long-term field trial where no nutrients have been added for approximately 50 years [46], thereby explaining the response to application of easily available P sources. The Castel soil was taken from an alkaline site where native $P$ is largely bound in calcium complexes. The Buus soil is from an organic field site where the plant available $\mathrm{P}$ fraction is indeed low $(\mathrm{P} C A \mathrm{~L}=6.5 \mathrm{mg} \mathrm{P} /$ $\mathrm{kg}$ ), but with a large organic $\mathrm{P}$ fraction (data not shown) which likely contributed to $\mathrm{P}$ supply during the experiment causing a moderate response to TSP addition.

\section{Variable $P$ fertilizer effects ( $P, B E 0)$}

We observed a range of responses due to the application of different $\mathrm{P}$ fertilizers. The calculated fertilizer efficiencies (Table 5) indicate that, in the absence of inoculated $\mathrm{BEs}$, recycling fertilizers (organic or inorganic) were superior to the rock phosphate fertilizer (the Castel experiment was an exception). The fertilizer and $\mathrm{P}$ use efficiencies for sewage sludge, and sewage sludge ashes were quite similar within the same experiment but quite different between the two experiments where these products were included (16-22\% for the Vörden experiment and $45-49 \%$ for the Taastrup experiment). This is in line with the data on water extractable $\mathrm{P}$ in the sludges where the level in the Danish sludge was three times higher than in the German sludge (Table 4). Furthermore, the availability of $\mathrm{P}$ in sewage sludge ashes can be quite different depending on the processing of the sludge in the water treatment plant [47].The very high fertilizer efficiency recorded for the P-enriched BOF slag has been observed earlier in wheat [45] and maize [42].

\section{Moderate effects in the absence of added P (P0, BE1-3)}

When no $P$ was added, the three BEs neither improved aboveground biomass nor P uptake. In one case (Castel-IT), there was even a reduced aboveground biomass due to the application of BE2 and BE3. The absence of response after $\mathrm{BE}$ application was observed in many other experiments $[45,48,49]$ and in particular in soils characterized by extraordinary low levels of available P (20 mg kg $\mathrm{g}^{-1}$ or lower) or that were limiting in other soil nutrients $[10,50,51]$. In contrast, other studies have shown that for maize and other crops, the application of BEs was more efficient in the absence of added $P$ fertilizers [36-38]. However, in these cases, soil $\mathrm{P}$ availability was distinctly higher and P CAL ranged between 35 and $45 \mathrm{mg} / \mathrm{kg}$.

The observed absence of plant responses to BE applications when soils are extremely low in available $\mathrm{P}$ could be explained by direct growth limitation of the host plants, which finally limits sufficient production of roots and root exudates to initiate beneficial plant-microbial interactions with indigenous or inoculated soil microbes in the rhizosphere. This phenomenon is well documented, e.g., for mycorrhizal associations frequently absent on extremely nutrient-impoverished soils $[52,53]$ or for the establishment of the Rhizobium symbiosis in leguminous plants on low P soils which is promoted by starter applications with soluble P [54]. Moreover, in the absence of significant soil $\mathrm{P}$ pools that can be mobilized by BEs, their presence will have no beneficial effect on plant $P$ supply, or may even be in competition with plants by immobilizing $\mathrm{P}$ in microbial tissue.

\section{BE effects depend on soil and fertilizer type}

In the present study, it was observed that for the three tested BEs, the soil strongly modulated the observed $\mathrm{BE}$ effect (Table 6). Various studies have shown that soil $\mathrm{pH}$, soil organic carbon content, soil microbial activity, and soil nutrient status are all influencing the success of $\mathrm{BE}$ application [16, 25, 55-57]. Our findings indicate that the most responsive soils to $\mathrm{BE}$ application (in combination with P fertilizers) were either alkaline (Castel-IT) or depleted in soil nutrients (Taastrup-DK and Vörden-DE for $\mathrm{P}$ acquisition), confirming the influence of soil $\mathrm{pH}$ and soil nutrient statues on the effectiveness of BEs. The type of fertilizer used along with BEs was also significantly influencing the magnitude of BE effects (Table 6). Since all tested fertilizers were different (with the exception of 


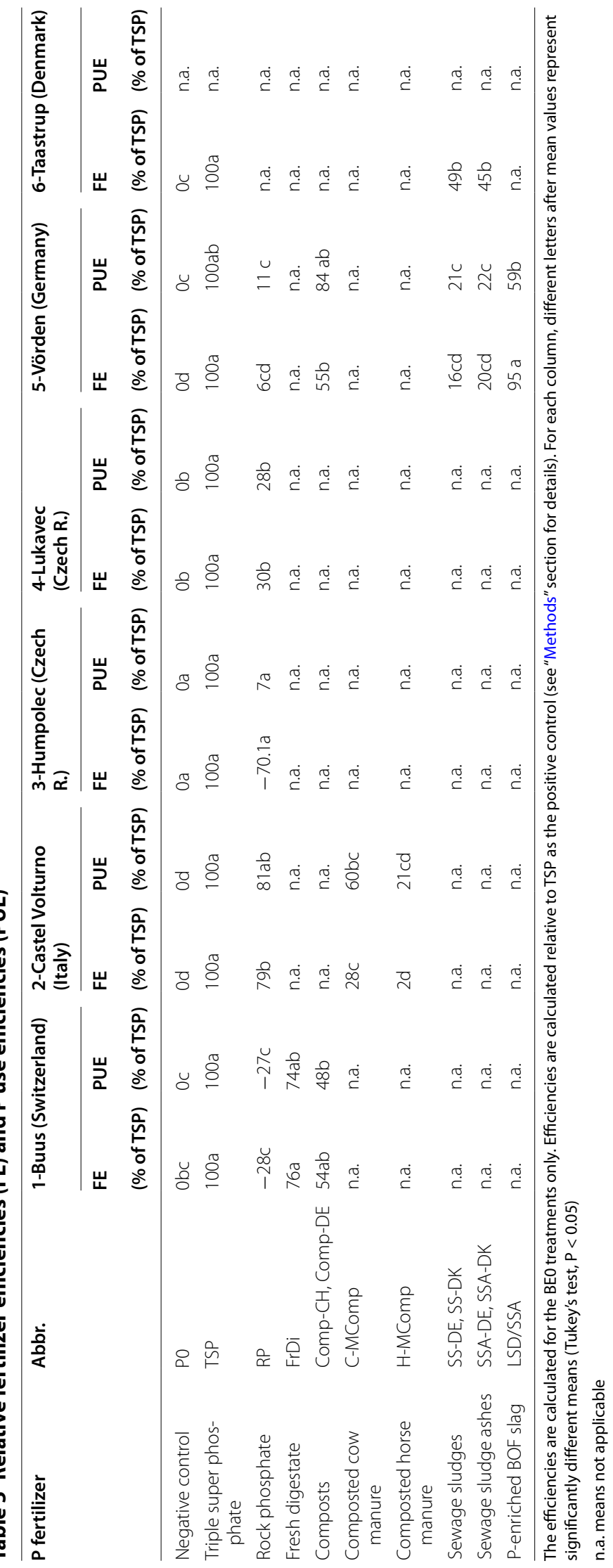


Table 6 Shoot biomass improvement (\%) of the different $B E$ treatments relative to the un-inoculated control (BEO)

\begin{tabular}{|c|c|c|c|}
\hline & $\begin{array}{l}\text { Trianum-P } \\
\text { (BE1) }\end{array}$ & Proradix (BE2) & Rhizovital (BE3) \\
\hline $\begin{array}{l}\text { Overall BE effect } \\
\text { (across all treat- } \\
\text { ments) }\end{array}$ & $7.5 \%$ & $5.2 \%$ & $6.0 \%$ \\
\hline $\begin{array}{l}\text { Number of } \\
\text { observations }\end{array}$ & 50 & 87 & 78 \\
\hline \multicolumn{4}{|c|}{ BE effect in the different soils (across all fertilizers types) } \\
\hline $\begin{array}{l}\text { Buus (Switzer- } \\
\text { land) }\end{array}$ & $2.7 \% \mathrm{~b}^{\mathrm{a}}$ & $0.4 \% b^{a}$ & $8 \% \mathrm{a}^{\mathrm{a}}$ \\
\hline Castel (Italy) & $12.3 \% \mathrm{a}^{\mathrm{a}}$ & $7.8 \% \mathrm{~b}^{\mathrm{a}}$ & $6.7 \% \mathrm{a}^{\mathrm{a}}$ \\
\hline $\begin{array}{l}\text { Vörden (Ger- } \\
\text { many) }\end{array}$ & Not measured & $3.4 \% a b^{a}$ & $3.6 \% b^{a}$ \\
\hline $\begin{array}{l}\text { Taastrup (Den- } \\
\text { mark) }\end{array}$ & Not measured & $17.0 \% \mathrm{a}^{\mathrm{a}}$ & Not measured \\
\hline \multicolumn{4}{|c|}{ BE effect with the different fertilizer types (across all soils) ${ }^{b}$} \\
\hline $\begin{array}{l}\text { No fertilizer } \\
\text { added }\end{array}$ & $10.8 \% \mathrm{a}^{\mathrm{a}}$ & $-1.2 \% \mathrm{~b}^{\mathrm{a}}$ & $-11.5 \% b^{a}$ \\
\hline $\begin{array}{l}\text { Organic ferti- } \\
\text { lizer }\end{array}$ & $6.9 \% a^{a}$ & $14.0 \% a^{a}$ & $13.0 \% a^{a}$ \\
\hline $\begin{array}{l}\text { Inorganic } \\
\text { fertilizer }\end{array}$ & $6.4 \% a^{a}$ & $1.5 \% \mathrm{~b}^{\mathrm{a}}$ & $7.3 \% \mathrm{a}^{\mathrm{a}}$ \\
\hline \multicolumn{4}{|c|}{ ANOVA on the effect of soil, fertilizer type and their interaction } \\
\hline Soil ( $p$ value) & $0.0002(d f=1)$ & $0.0070(d f=3)$ & $0.0054(d f=2)$ \\
\hline $\begin{array}{l}\text { Fertilizer type } \\
(p \text {-value })\end{array}$ & $\mathrm{ns}(d f=2)$ & $<0.0001(d f=2)$ & $<0.0001(d f=2)$ \\
\hline $\begin{array}{l}\text { Soil } x \text { fertilizer } \\
\text { type ( } p \text {-value) }\end{array}$ & $<0.0001(d f=2)$ & $<0.0001(d f=6)$ & $<0.0001(d f=4)$ \\
\hline \multicolumn{4}{|c|}{$d f$ means degree of freedom } \\
\hline \multicolumn{4}{|c|}{ See "Methods" section for description of the calculations } \\
\hline \multicolumn{4}{|c|}{$\begin{array}{l}\text { a Levels not connected by the same letter are significantly different (Tukey's } \\
\text { HSD test } P<0.05 \text { ) }\end{array}$} \\
\hline \multicolumn{4}{|c|}{$\begin{array}{l}{ }^{\mathrm{b}} \text { Underlined combinations of } \mathrm{BE} \text { and } \mathrm{P} \text { fertilizer type indicate when } \mathrm{BE} \text { addition } \\
\text { significantly improved shoot biomass as compared to the un-inoculated control } \\
\text { with the same fertilizer type }(t \text {-test with } P<0.05)\end{array}$} \\
\hline
\end{tabular}

TSP and RP that were tested in almost all experiments), we categorized them in two types (organic or inorganic) in order to investigate if there were some more general trends in the interaction between $\mathrm{P}$ fertilizer applied and the effect of the three BEs across the experiments. Clearly, BE2 and BE3 (both bacterial) applied with organic fertilizers were the best combinations and in particular when these BEs were combined with composted animal manures (for BE2 and BE3) or with the Danish sewage sludge (for BE2). In the Vörden soil, sewage sludge was also combined with BE2. But here, BE2 failed to exert any effect on the obtained biomass, showing again the complexity of these processes and why the interaction between soil and fertilizer type was significant in the performed two-way ANOVA (Table 6). In two cases (Buus and Castel soils), BE1 (fungal) was able to increase the aboveground biomass when combined with TSP, indicating that the three BEs have likely different modes of
Table 7 Aboveground P concentration ( $\mathrm{mg} / \mathrm{g})$

\begin{tabular}{|c|c|c|c|c|}
\hline & BEO & BE1 & BE2 & BE3 \\
\hline \multicolumn{5}{|l|}{ 1-Buus } \\
\hline Control P0 & $1.57 a$ & $1.45 a b$ & $1.44 a b$ & $1.29 b$ \\
\hline $\mathrm{TSP}$ & $1.97 a$ & $1.85 a$ & $1.89 a$ & $1.77 a$ \\
\hline $\mathrm{RP}$ & $1.42 \mathrm{a}$ & $1.49 a$ & $1.63 a$ & $1.44 a$ \\
\hline FrDi & $1.87 a b$ & $1.97 a$ & $1.94 a$ & $1.72 b$ \\
\hline Comp-CH & $1.76 a$ & $1.95 a$ & $1.91 \mathrm{a}$ & $1.91 \mathrm{a}$ \\
\hline \multicolumn{5}{|c|}{ 2-Castel Volturno } \\
\hline Control P0 & $0.96 c$ & $1.01 b c$ & $1.40 \mathrm{a}$ & $1.15 b$ \\
\hline $\mathrm{TSP}$ & $1.00 \mathrm{a}$ & $0.81 b$ & $0.84 a b$ & $0.85 a b$ \\
\hline $\mathrm{RP}$ & $1.00 \mathrm{a}$ & $0.98 a$ & $1.01 \mathrm{a}$ & $1.15 \mathrm{a}$ \\
\hline C-MComp & $1.20 \mathrm{~b}$ & $1.27 \mathrm{~b}$ & $1.50 \mathrm{a}$ & 1.39ab \\
\hline H-MComp & $1.13 b$ & $1.12 b$ & $1.48 \mathrm{a}$ & $1.35 \mathrm{ab}$ \\
\hline \multicolumn{5}{|l|}{ 3-Humpolec } \\
\hline Control P0 & $1.03 a$ & $1.03 a$ & $1.26 \mathrm{a}$ & $1.04 \mathrm{a}$ \\
\hline TSP & $1.28 \mathrm{a}$ & $1.27 \mathrm{a}$ & $1.29 a$ & $1.25 \mathrm{a}$ \\
\hline $\mathrm{RP}$ & $1.03 a$ & $1.01 \mathrm{a}$ & $1.26 a$ & $1.07 a$ \\
\hline \multicolumn{5}{|l|}{ 4-Lukavec } \\
\hline Control P0 & $0.88 a$ & $0.78 a$ & $1.10 a$ & $0.98 a$ \\
\hline $\mathrm{TSP}$ & $1.19 a$ & $1.19 a$ & $1.04 a$ & $1.11 \mathrm{a}$ \\
\hline $\mathrm{RP}$ & $0.99 a$ & $0.92 a$ & $0.82 a$ & $1.21 \mathrm{a}$ \\
\hline \multicolumn{5}{|l|}{ 5-Vörden } \\
\hline Control P0 & $1.12 \mathrm{a}$ & n.a. & $0.76 b$ & $1.14 \mathrm{a}$ \\
\hline TSP & $1.06 a$ & n.a. & $0.68 b$ & $1.15 \mathrm{a}$ \\
\hline $\mathrm{RP}$ & $1.28 \mathrm{a}$ & n.a. & $0.94 b$ & $1.05 b$ \\
\hline SS-DE & $1.23 a b$ & n.a. & $1.58 \mathrm{a}$ & $1.16 b$ \\
\hline SSA-DE & $1.15 b$ & n.a. & $1.62 a$ & $1.14 b$ \\
\hline Comp-DE & $1.45 \mathrm{a}$ & n.a. & $1.84 a$ & $1.58 a$ \\
\hline LSD/SSA & $0.75 b$ & n.a. & $1.17 a$ & $1.03 a$ \\
\hline \multicolumn{5}{|l|}{ 6-Taastrup } \\
\hline Control P0 & $1.99 a$ & n.a. & $1.71 b$ & n.a. \\
\hline SS-DK & $2.49 a$ & n.a. & $2.28 a$ & n.a. \\
\hline SSA-DK & $2.15 a$ & n.a. & $2.31 a$ & n.a. \\
\hline
\end{tabular}

For each row, means which are followed by different letters are significantly different (Tukey's HSD test $P<0.05$, performed within each $P$ treatment and for each soil)

n.a. means not applicable

action (see below). The study of Lekfeldt et al. [45] indicates that, to some extent, these effects and interactions are also crop specific since they did not observe any positive effects of BE1-3 on plant growth or P uptake when wheat was fertilized with recycling fertilizers.

\section{Possible modes of action}

Several studies $[27,39,58]$ have shown that, in in vitro conditions, many BEs are able to dissolve insoluble tricalcium phosphates by releasing protons and/or organic acids (e.g., gluconic acids), decreasing the $\mathrm{pH}$ of the growth medium and/or act as cation chelators $(\mathrm{Al}, \mathrm{Fe}$, and Ca) [59]. Nevertheless, in pot experiments where soil 
low in available $\mathrm{P}$ is used as the growth substrate, this solubilization ability was limited, as almost none of the BEs could increase plant P content in P0 and RP treatments, with the exception of BE1 in the alkaline Castel soil (P0 treatment,). This limited solubilization ability under in situ soil conditions was also observed in other studies $[27,45,49]$ and may be explained by the soil buffering capacity that inhibits the BE-induced soil acidification [33] that otherwise would have favored solubilization of calcium phosphates from soil and/or RP. However, we observed that in the Vörden soil, the amendment of sewage sludge ashes or P-enriched BOF slags (both inorganic fertilizers containing $\mathrm{P}$ in calcium phosphates complexes) increased plant $P$ uptake when they were inoculated with BE2 or BE3 (Fig. 3e). Since this was not associated with increased $\mathrm{N}$ content in shoot (Fig. 4e), we can exclude that the better acquisition of $\mathrm{P}$ is the result of improved root growth. Rather, it is possible that the higher $\mathrm{P}$ content and concentration (Fig. 3e and Table 7) measured in the shoots are indeed the result of $\mathrm{P}$ solubilization (from these fertilizers), induced by BEs and in particular BE2. Yet, it remains to be understood why the biomass of these plants was not larger than the BE0 control and why the same BE could not solubilize $P$ when combined with rock phosphate in the same soil.

Inoculated plants with higher biomass, $\mathrm{P}$, and $\mathrm{N}$ contents (in the Castel soil, BE1-3 with composted animal manures; or in the Taastrup soil, BE2 with sewage sludge) could result from $\mathrm{BE}$-induced mineralization of organic $\mathrm{P}$ and $\mathrm{N}$ contained in the tested organic fertilizers. For P, several studies have shown that phosphatase activities (acid and alkaline) measured in soil can be increased upon inoculation with BEs $[16-18,60]$. Although it was not measured in our experiments, we argue that increased mobilization of $\mathrm{P}$ from organic fertilizers via higher phosphatase activities is likely one of the major mechanisms behind the successful BE-organic fertilizer combinations observed in this study. Nevertheless, plants can also produce phosphatases, and therefore BEs may also have induced growth of more roots and these may in return have produced more of these enzymes. Indeed, the fact that BEs combined with TSP lead in some cases to higher aboveground biomass suggests that BEs can increase root growth and therefore the volume of soil explored for nutrient uptake. This mechanism has been described in several studies [6164 ] and results from the direct or indirect production of root growth regulators such as auxin.

The volume of soil explored for nutrient uptake can also be increased via higher root length colonization percentage (RLC \%) by AMF. In this study, the only roots analyzed for RLC \% were from the experiments with the Buus and Castel soils. In the latter case, an increase in
RLC \% after BE inoculation was recorded with or without application of P fertilizers (Fig. 5b). This mycorrhizal boosting effect is known for several microorganisms [65-67] and in particular for BE2 [68]. In the Castel soil, the increased RLC \% due to BE inoculation in combination with the P fertilization treatments P0, RP, and TSP did not necessarily translate into higher biomass or acquired $\mathrm{P}$. This indicates that the mycorrhizal boosting effect of $\mathrm{BE}$ inoculation in that soil was of minor importance for plant $\mathrm{P}$ uptake and growth, although we do not know to which degree it contributed to the improvement in P uptake and growth for the plants inoculated with the three BEs and amended with the animal manures. In the Buus soil (Fig. 5a), RLC \% was not increased after $\mathrm{BE}$ inoculation. This can be explained in part by the fact that roots were already highly colonized (almost 90\%). But it also seems that in some combinations, BE inoculation had a negative impact on RLC \% under these conditions, and this could be due to competition. Yet, the clear mechanisms remain to be explained.

\section{Conclusion}

We have observed that in our experiments, the most responsive soils for the three tested BEs were either alkaline or highly depleted in nutrients, and that a positive effect of the BEs was dependent on an input of $P$ fertilizer under these conditions. Of all tested fertilizers, the combination of $\mathrm{BE}$ with organic fertilizers (in particular composted animal manures) was the most promising. Nevertheless, the combination of BE and organic fertilizers was not always improving biomass production or P uptake (e.g., Buus soil). The next challenge will be to understand what properties of organic fertilizers make them more compatible with a given $\mathrm{BE}$ and how this interacts with soil parameters, such as soil pH, soil microbial activities, organic matter content, and soil $\mathrm{P}$ and $\mathrm{N}$ status. Regarding the mechanisms, the results from this study suggest that the three BEs likely improved root growth (volume of soil explored for nutrients uptake) and $P$ mobilization via accelerated mineralization, whereas chemical P solubilization likely took place in very few cases. Although higher mycorrhizal RLC\% were observed upon inoculation with the three BEs in the alkaline soil of Castel, it remains to be determined if this was the principal mechanism contributing to improved $\mathrm{P}$ acquisition and aboveground biomass in that experiment.

Clarification of mechanisms together with new experiments with more diverse soils and characterization of BE-compatible fertilizers will give further insights about the window of conditions leading to successful use of BEs in agriculture. Nevertheless, our results show which kind of soils and fertilizers type is more responsive to $\mathrm{BE}$ inoculation. 


\section{Authors' contributions}

The study was elaborated by PM, GN, AP, AdN, MK, MR, VC, MW, and CT. The experiments were performed by SS, CT, CM, FW, MR, MK, JSDL, and VC. The manuscript was written by $C T, J S D L$, and DK. All authors read and approved the final manuscript.

\section{Author details}

${ }^{1}$ Soil Sciences Department, Research Institute of Organic Agriculture FiBL, Ackerstrasse 113, 5070 Frick, Switzerland. ${ }^{2}$ Department of Plant and Environmental Sciences, University of Copenhagen, Copenhagen, Denmark. ${ }^{3}$ CERMANU-University of Naples Federico II, Naples, Italy. ${ }^{4}$ Department of Agro-environmental Chemistry and Plant Nutrition, Czech University of Life Sciences, Prague, Czech Republic. ${ }^{5}$ Agrofutura AG, Brugg, Switzerland. ${ }^{6}$ Institute of Crop Science 340h, University of Hohenheim, Stuttgart, Germany. ${ }^{7}$ Institut für Baustoff Forschung, Duisburg, Germany. ${ }^{8}$ Agroscope Reckenholz, Zurich, Switzerland.

\section{Acknowledgements}

This study was funded by the European Community's Seventh Framework Program 662 (FP7/2007-2013) under Grant Agreement no 312117 (BIOFECTOR) and by CORE Organic II (FP7 ERA-NET) under the Grant Agreement no 249667 (Improve-P).

\section{Competing interests}

All authors confirm that they have no competing interests in any of the products tested in this work, or any results presented in the manuscript.

\section{Availability of data and materials}

Raw data may be available on request to the authors, please contact corresponding author.

\section{Consent for publication}

All the authors consented for publication.

\section{Received: 30 August 2016 Accepted: 17 January 2017} Published online: 13 March 2017

\section{References}

1. Tilman D, Cassman KG, Matson PA, Naylor R, Polasky S. Agricultural sustainability and intensive production practices. Nature. 2002;418(6898):671-7

2. Tilman D, Fargione J, Wolff B, D'Antonio C, Dobson A, et al. Forecasting agriculturally driven global environmental change. Science. 2001:292(5515):281-4.

3. Vermeulen SJ, Campbell BM, Ingram JSI. Climate change and food systems. Ann Rev Environ Res. 2012;37(1):195-222.

4. Smil V. Phosphorous in the environment: natural Flows and Human Interferences. Annu Rev Energy Env. 2000;25(1):53-88.

5. Cordell D, Drangert JO, White S. The story of phosphorus: global food security and food for thought. Glob Environ Change. 2009;19(2):292-305.

6. Lynch JP, Brown KM. Topsoil foraging - an architectural adaptation of plants to low phosphorus availability. Plant Soil. 2001;237(2):225-37.

7. Dunbabin V, Armstrong R, Officer S, Norton R. Identifying fertiliser management strategies to maximise nitrogen and phosphorus acquisition by wheat in two contrasting soils from Victoria, Australia. Aus J Soil Res. 2009:47:74-90.

8. Adesemoye A, Kloepper J. Plant-microbes interactions in enhanced fertilizer-use efficiency. Appl Microbiol Biotechnol. 2009;85(1):1-12.

9. Fröhlich A, Buddrus-Schiemann K, Durner J, Hartmann A, Von R, et al. Response of barley to root colonization by Pseudomonas sp. DSMZ 13134 under laboratory, greenhouse, and field conditions. J Plant Interact. $2011 ; 7(1): 1-9$.

10. Nkebiwe PM, Weinmann M, Müller T. Improving fertilizer-depot exploitation and maize growth by inoculation with plant growth-promoting bacteria: from lab to field. Chem Biol Technol Agric. 2016;3(1):15-15.

11. Berg G. Plant-microbe interactions promoting plant growth and health: perspectives for controlled use of microorganisms in agriculture. Appl Microbiol Biotechnol. 2009:84(1):11-8.
12. Sharma HSS, Fleming C, Selby C. Plant biostimulants: a review on the processing of macroalgae and use of extracts for crop management to reduce abiotic and biotic stresses. J Appl Phycol. 2014;26(1):465-90.

13. Lugtenberg B, Kamilova F. Plant-growth-promoting rhizobacteria. Ann Rev Microbiol. 2009:63:541-56.

14. McNear DH Jr. The rhizosphere-roots, soil and everything in between. Nat Educ Knowl. 2013:4(3):1-1.

15. Sharma HSS, Selby C, Carmichael E, McRoberts C, Rao JR, et al. Physicochemical analyses of plant biostimulant formulations and characterisation of commercial products by instrumental techniques. Chem Biol Technol Agric. 2016;3(1):1-17.

16. Mäder P, Kaiser F, Adholeya A, Singh R, Uppal HS, et al. Inoculation of root microorganisms for sustainable wheat-rice and wheat-black gram rotations in India. Soil Biol Biochem. 2011;43(3):609-19.

17. Krey T, Caus M, Baum C, Ruppel S, Eichler-Lobermann B. Interactive effects of plant growth-promoting rhizobacteria and organic fertilization on P nutrition of Zea mays L. and Brassica napus L. J Plant Nutr Soil Sci. 2011;174(4):602-13.

18. Hussain M, Asghar H, Arshad M, Shahbaz M. Screening of multi-traits rhizobacteria to improve maize growth under axenic conditions. J Anim Plant Sci. 2013;23(2):514-20.

19. Cassán F, Vanderleyden J, Spaepen S. Physiological and agronomical aspects of phytohormone production by model plant-growth-promoting rhizobacteria (pgpr) belonging to the genus Azospirillum. J Plant Growth Regul. 2013;33(2):440-59.

20. Rodríguez $\mathrm{H}$, Fraga R. Phosphate solubilizing bacteria and their role in plant growth promotion. Biotechnology Advances. 1999; 17(4): 319-339.

21. Gaind S, Gaur A. Impact of fly ash and phosphate solubilising bacteria on soybean productivity. Bioresour Technol. 2002;85(3):313-5.

22. Jastrzębska M, Kostrzewska M, Treder K, Jastrzębski W, Makowski P. Phosphorus biofertilizers from ash and bones-agronomic evaluation of functional properties. J Agric Sci. 2016;8(6):58-70.

23. Garbaye J. Mycorrhization helper bacteria: a new dimension to the mycorrhizal symbiosis. Acta Bot Gallica. 1994;141(4):517-21.

24. Artursson V, Finlay R, Jansson J. Interactions between arbuscular mycorrhizal fungi and bacteria and their potential for stimulating plant growth. Environ Microbiol. 2006;8(1):1-10

25. Mosimann C, Oberhänsli T, Ziegler D, Nassal D, Kandeler E, et al. Tracing of two pseudomonas strains in the root and rhizoplane of maize, as related to their plant growth-promoting effect in contrasting soils. Front Microbiol. 2017;7:2150.

26. Ryan MH, van Herwaarden AF, Angus JF, Kirkegaard JA. Reduced growth of autumn-sown wheat in a low-P soil is associated with high colonisation by arbuscular mycorrhizal fungi. Plant Soil. 2005;270(1-2):275-86.

27. Menzies N, Bell M, Dart P. Soil additives to stimulate N fixing and P availability — science, myth and legend. Barton: Dubbo Grains Research Update, GRDC; 2009. p. 172-88.

28. Buddrus-Schiemann K, Schmid M, Schreiner K, Welzl G, Hartmann A. Root colonization by Pseudomonas sp. DSMZ 13134 and impact on the indigenous rhizosphere bacterial community of barley. Microb Ecol. 2010:60(2):381-93.

29. Postma JA, Lynch JP. Theoretical evidence for the functional benefit of root cortical aerenchyma in soils with low phosphorus availability. Ann Bot. 2011;107(5):829-41.

30. Walker V, Bertrand C, Bellvert F, Moenne-Loccoz Y, Bally R, et al. Host plant secondary metabolite profiling shows a complex, strain-dependent response of maize to plant growth-promoting rhizobacteria of the genus Azospirillum. New Phytol. 2011;189(2):494-506.

31. Gholami A, Shahsavani S, Nezarat S. The Effect of plant growth promoting Rhizobacteria (PGPR) on germination, seedling growth and yield of maize. Proc World Acad Sci. 2009;3(1):19-24.

32. Rosas SB, Avanzini G, Carlier E, Pasluosta C, Pastor N, et al. Root colonization and growth promotion of wheat and maize by Pseudomonas aurantiaca SR1. Soil Biol Biochem. 2009:41(9):1802-6.

33. VDLUFA. VDLUFA-Methodenbuch. Band I: Die Untersuchung von Böden. 4 ed. 1991, Darmstadt: VDLUFA-Verlag.

34. Altomare C, Norvell W, Björkman T, Harman G. Solubilization of phosphates and micronutrients by the plant-growth-promoting and biocontrol fungus Trichoderma harzianum Rifai 1295-22. Appl Environ Microbiol. 1999;65(7):2926-33. 
35. Adams P, De-Leij F, Lynch J. Trichoderma harzianum Rifai 1295-22 mediates growth promotion of crack willow (Salix fragilis) saplings in both clean and metal-contaminated soil. Microb Ecol. 2007;54(2):306-13.

36. Rudresh DL, Shivaprakash MK, Prasad RD. Tricalcium phosphate solubilizing abilities of Trichoderma spp. in relation to $P$ uptake and growth and yield parameters of chickpea (Cicer arietinum L.). Can J Microbiol. 2005;51(3):217-22.

37. Akladious S, Abbas S. Application of Trichoderma harzianum T22 as a biofertilizer potential in maize growth. J Plant Nutr. 2014;37(1):30-49.

38. Buddrus-Schiemann K, Schmid M, Schreiner K, Welzl G, Hartmann A. Root colonization by Pseudomonas sp. DSMZ 13134 and impact on the indigenous rhizosphere bacterial community of barley. Microb Ecol. 2010;60(2):381-93.

39. Fröhlich A, Buddrus-Schiemann K, Durner J, Hartmann A, von Rad U. Response of barley to root colonization by Pseudomonas sp. DSMZ 13134 under laboratory, greenhouse, and field conditions. J Plant Interact. 2012;7(1):1-9.

40. Borriss R. Use of plant-associated Bacillus strains as biofertilizers and biocontrol agents in agriculture, in Bacteria in agrobiology: plant growth responses. Berlin: Springer; 2011. p. 41-76.

41. Bákonyi N, Gajdos E, Lévai L, Veres S, Tóth B, et al. Comparison of effects of different biofertilisers on early development of cucumber and wheat seedlings. in Zbornik Radova 44. Hrvatski i 4 Medunarodni Simpozij Agronoma, Opatija, Hrvatska, 16-20 Veljače 2009. 2009. Poljoprivredni Fakultet Sveučilišta Josipa Jurja Strossmayera u Osijeku.

42. Severin M, Breuer J, Rex M, Stemann J, Adam C, et al. Phosphate fertilizer value of heat treated sewage sludge ash. Plant Soil Environ. 2014;60(12):555-61.

43. Phillips JM, Hayman DS. Improved procedures for clearing roots and staining parasitic and vesicular-arbuscular mycorrhizal fungi for rapid assessment of infection. Trans Br Mycol Soc. 1970;55(1):158.

44. Brundrett $M$, Piché $Y$, Peterson R. A new method for observing the morphology of vesicular-arbuscular mycorrhizae. Can J Bot. 1984;62:2128-34.

45. Lekfeldt J, Rex M, Merclc F, Kulhánek M, Tlustoš P, et al. Effect of bioeffectors and recycled P-fertiliser products on the growth of spring wheat. Chem Biol Technol Agric. 2016 (in press).

46. van der Bom F, Magid J, Stoumann Jensen L. Long-term P and K fertilisation strategies and balances affect soil availability indices, crop yield depression risk and $\mathrm{N}$ use efficiency. Eur J Agron. (under revision)

47. Nanzer S, Oberson A, Huthwelker T, Eggenberger U, Frossard E. The molecular environment of phosphorus in sewage sludge ash: implications for bioavailability. J Environ Qual. 2014;43(3):1050-60.

48. Kundel D. Bio-effector application: impact on growth performance of maize and effect on associated arbuscular mycorrhizal fungi. University of Constance: Konstanz; 2016.

49. Neumann G. 2nd Periodic report. Resource preservation by application of bioeffectors in European crop production., technical report. 2015.

50. Dutta D, Bandyopadhyay P. Performance of chickpea (Cicer arietinum L.) to application of phosphorus and bio-fertilizer in laterite soil. Arch Agron Soil Sci. 2009;55(2):147-55.

51. Kaur G, Reddy M. Role of phosphate-solubilizing bacteria in improving the soil fertility and crop productivity in organic farming. Arch Agron Soil Sci. 2014;60(4):549-64.

52. Lambers H, Ahmedi I, Berkowitz O, Dunne C, Finnegan PM, et al. Phosphorus nutrition of phosphorus-sensitive Australian native plants: threats to plant communities in a global biodiversity hotspot. Conserv Physiol. 2013:1(1):1-23.
53. Teste FP, Laliberte E, Lambers H, Auer $Y$, Kramer S, et al. Mycorrhizal fungal biomass and scavenging declines in phosphorus-impoverished soils during ecosystem retrogression. Soil Biol Biochem. 2016;92:119-32.

54. Mmbaga GW, Mtei KM, Ndakidemi PA. Extrapolations on the use of rhizobium inoculants supplemented with phosphorus $(P)$ and potassium (K) on growth and nutrition of legumes. Agric Sci. 2014;5:1207-26.

55. Egamberdiyeva D. The effect of plant growth promoting bacteria on growth and nutrient uptake of maize in two different soils. Appl Soil Ecol. 2007;36(2-3):184-9.

56. Shaharoona B, Arshad M, Zahir ZA, Khalid A. Performance of Pseudomonas spp. containing ACC-deaminase for improving growth and yield of maize (Zea mays L.) in the presence of nitrogenous fertilizer. Soil Biol Biochem. 2006;38(9):2971-5.

57. Fliessbach A, Winkler M, Lutz M, Oberholzer H, Mader P. Soil amendment with Pseudomonas fluorescens CHAO: lasting effects on soil biological properties in soils low in microbial biomass and activity. Microb Ecol. 2009;57(4):611-23.

58. Khan M, Zaidi A, Wani P. Role of phosphate-solubilizing microorganisms in sustainable agriculture-a review. Agron Sustain Dev. 2007;27(1):29-43.

59. Jha A, Jha S, Baidya D. Ecological diversity, mechanism, and biotechnology of phosphate-solubilizing bacteria for enhanced crop production, in phosphate solubilizing microorganisms. Berlin: Springer; 2014. p. 157-74.

60. Hu X, Roberts D, Xie L, Maul J, Yu C, et al. Development of a biologically based fertilizer, incorporating Bacillus megaterium A6, for improved phosphorus nutrition of oilseed rape. Can J Microbiol. 2013;59(4):231-6.

61. Vacheron J, Desbrosses G, Bouffaud ML, Touraine B, Moenne-LoccozY, et al. Plant growth-promoting rhizobacteria and root system functioning. Front Plant Sci. 2013:4:356-75.

62. Dobbelaere S, Vanderleyden J, Okon Y. Plant growth-promoting effects of diazotrophs in the rhizosphere. Crit Rev Plant Sci. 2003;22(2):107-49.

63. Combes-Meynet E, Pothier J, Moenne-Loccoz Y, Prigent-Combaret C. The pseudomonas secondary metabolite 2,4-diacetylphloroglucinol is a signal inducing rhizoplane expression of Azospirillum genes involved in plant-growth promotion. Molr Plant Microbe Interact. 2011;24(2):271-84.

64. Chamam A, Sanguin H, Bellvert F, Meiffren G, Comte G, et al. Plant secondary metabolite profiling evidences strain-dependent effect in the Azospirillum-Oryza sativa association. Phytochemistry. 2013;87:65-77.

65. Bidondo LF, Colombo R, Bompadre J, Benavides M, Scorza V, et al. Cultivable bacteria associated with infective propagules of arbuscular mycorrhizal fungi. Implications for mycorrhizal activity. Appl Soil Ecol. 2016;105:86-90.

66. Panneerselvam P, Mohandas S, Saritha B, Upreti KK, Poovarasan S, et al. Glomus mosseae associated bacteria and their influence on stimulation of mycorrhizal colonization, sporulation, and growth promotion in guava (Psidium guajava L.) seedlings. Biol Agric Hortic. 2012;28(4):267-79.

67. Srinath J, Bagyaraj DJ, Satyanarayana BN. Enhanced growth and nutrition of micropropagated Ficus benjamina to Glomus mosseae co-inoculated with Trichoderma harzianum and Bacillus coagulans. World J Microbiol Biotechnol. 2003;19(1):69-72.

68. Yusran Y, Roemheld V, Mueller T. Effects of Pseudomonas sp. "Proradix" and Bacillus amyloliquefaciens FZB42 on the establishment of amf infection, nutrient acquisition and growth of tomato affected by Fusarium oxysporum Schlecht f.sp. radicis-lycopersici Jarvis and shoemaker. eScholoarship Repository, University of California. 2009; 1106. 